NIOSH FIRE FIGHTER FATALITY INVESTIGATION AND PREVENUION PROGRAM

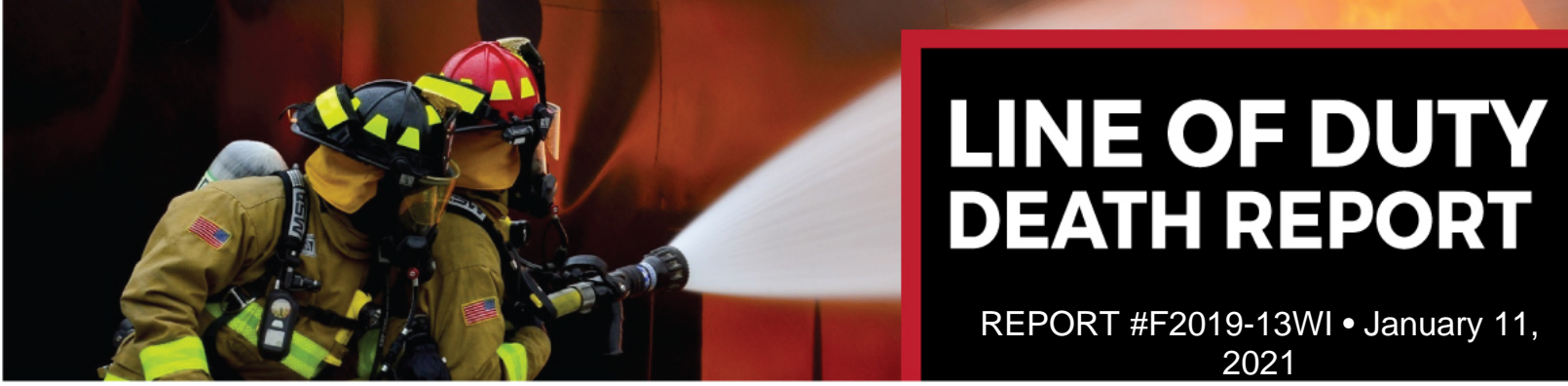

1000 FREDERICK LANE, MORGANTOWN, WV 26508 $\cdot 304.285 .5916$

\title{
Career Firefighter Killed, a Police Officer and a Civilian Wounded When They Were Shot During EMS Incident-Wisconsin
}

\section{Executive Summary}

On May 15, 2019, a career firefighter was killed, and a police officer and a civilian were injured after being shot while on an emergency medical services (EMS) incident involving a patient who overdosed. The firefighter was part of a three-person crew on engine 9321 that was dispatched along with a private ambulance company at approximately 5:30 p.m. to the report of a patient who had a seizure on a public bus at a bus terminal. A police officer was first on scene.

The unconscious patient was successfully treated with naloxone on the bus by a paramedic and regained consciousness. The patient and responders then exited the bus at 5:47 p.m. A second police officer arrived after the patient walked off the bus.

The police officers, fire, and EMS crews believed that the naloxone would wear off and were concerned for the patient's continued well-being. All of the responders expressed their concerns for the patient's well-being to the patient multiple times. Because all of the responders believed the patient would need additional medical assistance and should be transported to a local hospital for follow-up medical care, the police officers asked the patient repeatedly if he had anything on his person that could harm the fire and/or EMS responders. During this conversation, the patient abruptly produced a concealed handgun and began firing at the responders. Police officers immediately returned fire as they moved to cover. The fire and EMS crews also ran for cover. The patient/shooter and police officers exchanged gun fire. One firefighter was shot within 3 seconds of the handgun being produced by the patient and collapsed while seeking cover. He was found unresponsive approximately 80 seconds later and treated at the scene and transported to a local hospital where he was pronounced dead. A police officer was shot while returning gun fire. The patient/shooter took a civilian bystander as a hostage and continued to fire until the patient/shooter was shot and fell to the ground. The civilian hostage was also shot. The patient/shooter was secured, provided medical treatment for his injuries and transported to a local hospital where he was pronounced dead. The wounded police officer was transported to a local hospital by a fellow police officer. The wounded civilian was transported by ambulance to a local hospital. Both the wounded police officer and civilian were treated at local hospitals and recovered. The first gun shot was fired by the patient at 6:09 p.m. This was 39 minutes after the arrival of emergency responders and 22-minutes after exiting the bus. 


\section{Career Firefighter Killed, a Police Officer and a Civilian Wounded When They Were Shot During EMS Incident-Wisconsin}

\section{Contributing Factors}

- Medical Emergency: When firefighters first responded to the scene, the patient (prior to the shooting) was not breathing adequately and required emergency medical attention. An autopsy confirmed the patient/shooter had methamphetamine, fentanyl, and 4-anilino- $N$-phenethylpiperidine (4-ANPP, a metabolite of fentanyl or fentanyl analogues) in his system.

- Scene Safety and Situational Awareness: After being revived with intravenous naloxone and exiting the bus under his own power, the patient produced a concealed handgun and fired at numerous firefighters, law enforcement, EMS, other workers, and civilians. Prior to the shooting, police officers made multiple attempts but did not complete a search of the patient.

\section{Key Recommendations}

- First responders and agencies who deliver medical assistance to patients who overdose should train staff on standard operating procedures (SOPs) for naloxone administration, including an understanding of the objective of naloxone therapy and the possibility, albeit unusual, of agitation and combativeness from persons after receiving naloxone.

- Fire, EMS, and police departments should take steps to help ensure scene safety including taking all necessary actions to protect themselves when providing lifesaving care to a patient. The fire service and standards setting organizations should consider developing scene safety SOPs and training that provide more detailed guidance on the specifics of keeping first responders safe while providing lifesaving care to patients.

- Authorities Having Jurisdiction (AHJs) (e.g. municipalities, areas, or departments) should consider developing SOPs or guides that specify when (1) a patient should receive a pat down to identify information that might be useful for patient care or identify items that pose a threat to the patient or responders and (2) a patient might be restrained if the patient poses a threat to themselves or the responders. These SOPs should specify who determines when a pat down is necessary and who is authorized to perform it. These SOPs should be operationalized, trained, and exercised by law enforcement, the fire service, and EMS as part of a Unified Command response.

The National Institute for Occupational Safety and Health (NIOSH) initiated the Fire Fighter Fatality Investigation and Prevention Program to examine deaths of fire fighters in the line of duty so that fire departments, fire fighters, fire service organizations, safety experts and researchers could leam from these incidents. The primary goal of these investigations is for NIOSH to make recommendations to prevent similar occurrences. These NIOSH investigations are intended to reduce or prevent future fire fighter deaths and are completely separate from the rulemaking, enforcement and inspection activities of any other federal or state agency. Under its program, NIOSH investigators interview persons with knowledge of the incident and review available records to develop a description of the conditions and circumstances leading to the deaths in order to provide a context for the agency's recommendations. The NIOSH summary of these conditions and circumstances in its reports is not intended as a legal statement of facts. This summary, as well as the conclusions and recommendations made by NIOSH, should not be used for the purpose of litigation or the adjudication of any claim.

For further information, visit the program Web site at www.cdc.gov/niosh/fire or call toll free 1-800-CDC-INFO (1-800-232-4636). 


\section{Career Firefighter Killed, a Police Officer and a Civilian Wounded When They Were Shot During EMS Incident-Wisconsin}

\section{Introduction}

On May 15, 2019, a career firefighter was fatally shot while on an EMS call for a drug overdose on a public intercity bus (Photo 1). A police officer and a civilian were also injured.

On June 4, 2019, the fire department contacted the NIOSH Firefighter Fatality Investigation and Prevention Program (FFFIPP) and requested assistance with an independent investigation of the incident.

On July 8, 2019, a NIOSH Medical Officer in the Hazard Evaluations and Technical Assistance Branch, Division of Field Studies and Engineering; a Senior Industrial Hygienist and Captain in the U.S. Public Health Service from the NIOSH Emergency Preparedness and Response Office; an Investigator/Safety and Occupational Health Specialist and an Investigator/Engineer with the NIOSH FFFIPP in the NIOSH Division of Safety Research traveled to Wisconsin to investigate this incident. The NIOSH investigators met with senior staff officers and representatives of the fire department. The NIOSH investigators met with

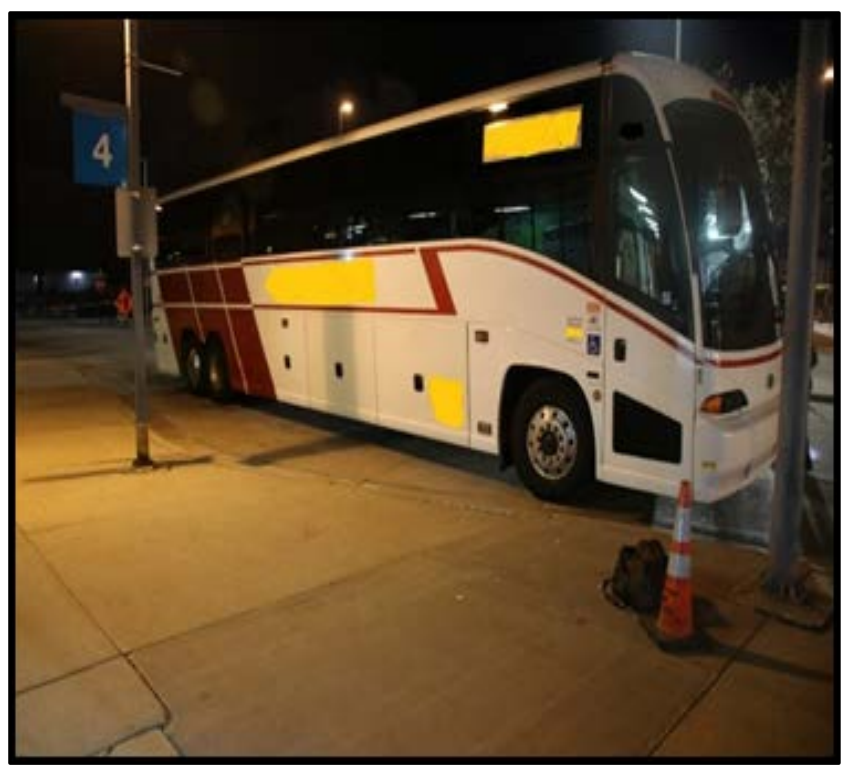

Photo 1. Incident scene. A career firefighter was killed, a police officer and a civilian were injured after being shot on an EMS incident after a patient who overdosed was revived and exited this bus. (Photo 1, courtesy local fire department, bus identification markings altered by NIOSH.) and interviewed the career firefighters and fire department officers and the private EMS ambulance crew involved in the incident. The NIOSH investigators obtained and reviewed fire department training records, standard operating procedures (SOPs), incident scene photographs and drawings, training records, and medical records. The police officers who responded were not available to be interviewed. However, a redacted version of the official police report was provided from the neighboring police department that investigated the incident. The neighboring police department also provided redacted body camera footage for review by NIOSH investigators.

\section{Fire Department}

The fire department involved in this incident is a career department consisting of 87 uniformed members that provide fire suppression and non-transport first responder level, EMS protection. The fire department employs a total of 96 staff including 4 personnel in administration, 3 personnel in fire prevention and public education and 2 personnel in resource development and special operations. There are 6 fire stations located strategically throughout the city that serve a population of approximately 74,100 in a geographic area of approximately 25 square miles. These 6 stations house 8 


\section{Career Firefighter Killed, a Police Officer and a Civilian Wounded When They Were Shot During EMS Incident-Wisconsin}

heavy apparatus: 5 engines, 1 ladder truck, 1 Quint, and 1 command vehicle. The department also has trained personnel that cross-staff a heavy rescue truck, 2 water rescue craft, and a rapid response light rescue/hazardous materials unit.

The department has one Chief, one Deputy Chief, five Battalion Chiefs with one Battalion Chief on duty per shift, one Battalion Chief of fire prevention and public education, and one Battalion Chief of resource development and special operations. The Battalion Chiefs and career firefighters are assigned to one of 3 shifts that work 48 hours on and 96 hours off duty with a daily staffing of 29 personnel. The fire department does not utilize chief's aides or incident command technicians.

In 2018, the department responded to approximately 5030 incidents with approximately 3350 of those listed as EMS and rescue calls. The fatally injured firefighter responded from a station that responded to approximately 1400 emergency calls (909 of those were emergency medical service calls and rescue requests) in 2018.

The department has automatic mutual aid agreements with surrounding jurisdictions for EMS and structural fires. The department utilizes a county-wide computer aided dispatch system for emergency incidents in their city and a neighboring city and they also utilize a neighboring computerized dispatch system for emergency response in those counties. Under the automatic mutual aid agreements, the department responded to those jurisdictions 96 times in 2018. They also regularly train with those jurisdictions. The department also participates in the MABAS (Mutual Aid Box Alarm System) for statewide requests and had 9 MABAS related requests for assistance in 2018.

All members of this department are trained and licensed as either Emergency Medical Responders/First Responders (EMRs with Advanced Skills), Emergency Medical Technicians-Basic (EMT-Bs), or Emergency Medical Technicians-Paramedic (EMT-Ps) by the state of Wisconsin. In 2018, the department focused on training plans to upgrade their service to a full Emergency Medical Technician-Basic service. Emergency medical ambulance service, including transport, Basic Life Support (BLS), and Advanced Life Support (ALS), is provided by a private ambulance service.

In 2018, the department conducted pre-employment physical and psychological examinations for new hires and candidates in their promotional processes. All personnel directly involved in firefighting activities participate in the annual physical fitness testing.

The department reported that it has taken a proactive role in developing health and wellness programs that address the mental well-being and physical fitness of their firefighters. In 2018, a Health and Wellness Committee was formed to address the needs of firefighters, including behavioral health. Several fire department members participated in training on peer support and critical incident stress management. The department also engaged in wellness presentations with a member of the fire service trained in peer support and a licensed clinician that specialized in post tramatic stress disorder.

Firefighter health programs are guided by National Fire Protection Association (NFPA) 1582, Standard on Comprehensive Occupational Medical Program for Fire Departments [NFPA 2018a]. 


\section{Career Firefighter Killed, a Police Officer and a Civilian Wounded When They Were Shot During EMS Incident-Wisconsin}

\section{Training and Experience}

The state of Wisconsin requires training for firefighters that meets or exceeds the requirements of National Fire Protection Association (NFPA) 1001, Standard for Firefighter Professional Qualifications, [NFPA 2013a] for the topic areas of Firefighter I, Hazardous Materials Awareness, Hazardous Materials Operations, and First Responder. The state does not require annual recertification.

The fire department involved in this incident has a process that utilizes the local technical college Public Safety Training Center and a regional fire department hiring process to train and hire firefighters. The recruits are then required to complete an internal 6-week recruit academy and successfully complete an 18-month probation period.

A detailed description of the technical college's Public Safety Training Center as well as the department's training location is available in the Appendix A.

In the state of Wisconsin, administration of intranasal naloxone is within the scope of practice for the EMS provider categories in this fire department [Wisconsin Department of Health Services 2019]. Naloxone for intranasal use is carried on the department's EMS equipment. The department has a standard operating guideline for responding to "opiate overdose.” This standard operating guideline suggests considering the administration of intranasal naloxone in $0.5 \mathrm{mg}$ increments up to a maximum of $2 \mathrm{mg}$ to unresponsive persons suspected of having an opioid overdose. The standard operating guideline reminds EMS providers that the objective of naloxone therapy is to "increase respiratory drive.” It also informs EMS providers of the potential for a patient to become violent after receiving naloxone.

The career firefighter fatally shot in this incident had 14 years of fire service experience with this department. Fire department training records indicated that he had received training and certification in Firefighter I, Firefighter II, Hazardous Materials Technician, Fire Inspector, Fire Officer, Structural Collapse Technician, Emergency Vehicle Operator, Pump Operator, Aerial Apparatus Operator, Truck Company Operations, National Fire Academy Responding to Terrorism Basic Concepts, Emergency Medical Technician (EMT) training and certification, and was a Certified Fire Investigator. The career firefighter was working on his normal shift at the time of the incident. He was assigned to be the acting driver/engineer on engine 9321.

Although this incident began as a medical assist call and did not involve a known active shooter when it initially occurred, the following information describes the fire department's on-going training and planning for an active shooter event. The fire department in this incident had an established program and related policies for a response to an “Active Shooter and Rescue Task Force” event or incident. This included working with law enforcement agencies and EMS to develop and deliver hands-on training and equip their personnel with personal protective equipment (PPE). Over the past six-years, training and equipping of the fire department for an active shooter event resulted in having ballistic PPE issued for each riding position of all apparatus including the command vehicles. Additionally, members of the fire department worked collaboratively with law enforcement to provide Tactical Emergency Casualty Care (TECC) certified paramedics for their Special Weapons and Tactics (SWAT) Team. In addition to basic fire suppression training conducted in 2018, the department successfully developed procedures to prepare for a response to an "Active Shooter and Rescue Task Force" event or incident. 


\section{Career Firefighter Killed, a Police Officer and a Civilian Wounded When They Were Shot During EMS Incident-Wisconsin}

\section{Equipment and Personnel}

Units that initially responded to the report of a seizure on a bus:

- Engine 9321 with three personnel including an officer (lieutenant noted as FF 2), the victim (noted as FF 1), who was the driver of Engine 9321, and a jumpseat firefighter (noted as FF 3).

- Private ambulance with two paramedics.

- Self-dispatched police officer.

\section{Timeline}

The following timeline is a summary of events that occurred as the incident evolved. Not all incident events are included in this timeline. The times are approximate and were obtained by studying the dispatch records, audio recordings, witness statements, and other information in the report from the neighboring police department that investigated the incident. All times are based on the redacted body camera footage and redacted police report that contained the transit station closed circuit television footage timeline.

Key:

- LEO: Law Enforcement Officer

- FF: Firefighter

- TS: Transit Station

- CCTV: Closed Circuit Television

\begin{tabular}{|c|c|c|}
\hline EVENT & TIME & SOURCE \\
\hline 911 medical emergency call received from TS. & $17: 32: 30$ & LEO 1 \\
\hline A TS employee boarded bus. & $17: 36: 00$ & TS CCTV \\
\hline TS security officer boarded bus. & $17: 36: 48$ & TS CCTV \\
\hline LEO 1 arrived. & $17: 42: 30$ & LEO 1 \\
\hline Engine 9321 arrived and crew boarded bus. & $17: 42: 35$ & TS CCTV \\
\hline $\begin{array}{l}\text { Engine } 9321 \text { crew made contact with TS employee and } \\
\text { unresponsive patient. }\end{array}$ & $17: 43: 00$ & LEO 1 \\
\hline Firefighter (FF) 3 performed sternal rub. Patient unresponsive. & $17: 43: 27$ & LEO 1 \\
\hline LEO 1 collected nearby bus riders’ observations. & $17: 43: 45$ & LEO 1 \\
\hline
\end{tabular}




\section{Career Firefighter Killed, a Police Officer and a Civilian Wounded When They Were Shot During EMS Incident-Wisconsin}

\begin{tabular}{|c|c|c|}
\hline FF 2 and FF 3 provided medical attention to patient. & $17: 43: 50$ & LEO 1 \\
\hline $\begin{array}{l}\text { Private ambulance with Paramedic } 1 \text { and Paramedic } 2 \text { arrived } \\
\text { on scene. }\end{array}$ & $17: 44: 15$ & CCTV \\
\hline LEO 1 contacted his supervisor. & $17: 45: 19$ & LEO 1 \\
\hline $\begin{array}{l}\text { FF } 3 \text { advised LEO } 1 \text { that the event was related to drugs, not a } \\
\text { seizure as originally reported. }\end{array}$ & $17: 46: 21$ & LEO 1 \\
\hline $\begin{array}{l}\text { LEO } 1 \text { checked garbage in the bathroom of the bus for signs } \\
\text { of drug use. }\end{array}$ & $17: 47: 15$ & LEO 1 \\
\hline $\begin{array}{l}\text { Paramedic } 1 \text { administered naloxone }(0.5 \mathrm{mg}) \text { intravenously to } \\
\text { patient. }\end{array}$ & $17: 49: 45$ & LEO 1 \\
\hline Patient responded to intravenous naloxone but was dazed. & $17: 50: 36$ & LEO 1 \\
\hline LEO 1 called police supervisor. & $17: 51: 24$ & LEO 1 \\
\hline $\begin{array}{l}\text { Paramedic } 1 \text { administered a second dose of naloxone }(0.5 \mathrm{mg}) \\
\text { intravenously to patient. }\end{array}$ & $17: 51: 15$ & LEO1 \\
\hline $\begin{array}{l}\text { LEO } 1 \text { called second person (likely police) to explain } \\
\text { situation. Responders continued to talk with patient. }\end{array}$ & $17: 52: 45$ & LEO 1 \\
\hline Paramedic advised patient he needed to go to the hospital. & $17: 54: 40$ & LEO 1 \\
\hline $\begin{array}{l}\text { LEO } 1 \text { also advised patient that he needed to go to the } \\
\text { hospital. }\end{array}$ & $17: 54: 45$ & LEO 1 \\
\hline Patient stated he took his wife's morphine pills on the bus. & $17: 56: 05$ & LEO 1 \\
\hline $\begin{array}{l}\text { LEO } 1 \text { asked Dispatch for a second unit. LEO } 2 \text { was } \\
\text { dispatched. }\end{array}$ & $17: 56: 30$ & LEO 1 \\
\hline Patient walked off the bus under his own power. & $17: 57: 00$ & LEO 1 \\
\hline $\begin{array}{l}\text { Once patient was off the bus, LEO } 1 \text { asked to check patient's } \\
\text { pockets to make sure he did not have anything sharp. }\end{array}$ & $17: 57: 20$ & LEO 1 \\
\hline
\end{tabular}




\section{Career Firefighter Killed, a Police Officer and a Civilian Wounded When They Were Shot During EMS Incident-Wisconsin}

\begin{tabular}{|c|c|}
\hline $\begin{array}{l}\text { Patient sat on cot facing LEO } 1 \text { and ignored LEO 1's request } \\
\text { for a pat down (first request). }\end{array}$ & $17: 57: 21$ \\
\hline $\begin{array}{l}\text { LEO } 1 \text { asked patient if he could 'check him out real quick' } \\
\text { (second request). }\end{array}$ & $17: 57: 38$ \\
\hline Patient asked to stand up. & $17: 57: 39$ \\
\hline $\begin{array}{l}\text { LEO } 1 \text { stated “yes, it would be helpful if you don’t mind if I } \\
\text { pat you down real quick” (third request). }\end{array}$ & $17: 57: 41$ \\
\hline Patient stated, "I have a problem with that". & $17: 57: 44$ \\
\hline $\begin{array}{l}\text { LEO } 1 \text { asked whether there is “anything on you that can hurt } \\
\text { these guys?” Patient states, “No, Sir.” LEO } 1 \text { asked, "how } \\
\text { come you have a problem with that?” }\end{array}$ & $17: 57: 49$ \\
\hline Patient stated, “because I don’t know what I have on me.” & $17: 57: 54$ \\
\hline $\begin{array}{l}\text { LEO } 1 \text { explained to the patient what happened to him and } \\
\text { wanted to triple check (fourth request). }\end{array}$ & $17: 58: 00$ \\
\hline $\begin{array}{l}\text { Patient ignored LEO } 1 \text { and started to stretch. Patient stated he } \\
\text { took } 4 \text { morphine pills prescribed for his wife. Patient turned } \\
\text { his right side away from LEO } 1 \text { and up against the front of the } \\
\text { bus. }\end{array}$ & $17: 58: 25$ \\
\hline $\begin{array}{l}\text { LEO } 1 \text { told patient, "I am going to pat you down” (fifth } \\
\text { statement). }\end{array}$ & 17:59:05 \\
\hline $\begin{array}{l}\text { Patient put his hands up to LEO } 1 \text { to avoid contact and said, } \\
\text { "Wait, I need to check myself first." }\end{array}$ & 17:59:07 \\
\hline Patient began emptying his pockets. & 17:59:16 \\
\hline $\begin{array}{l}\text { LEO } 1 \text { asked, “Can I pat you down real quick then?” Patient } \\
\text { ignored this request and continued digging in his pockets. } \\
\text { LEO } 1 \text { states “It doesn't have to be a big deal. I just want to } \\
\text { get you medical treatment” (sixth request). }\end{array}$ & $17: 59: 25$ \\
\hline Patient stated, “I don’t ne & $17: 59: 42$ \\
\hline
\end{tabular}




\section{Career Firefighter Killed, a Police Officer and a Civilian Wounded When They Were Shot During EMS Incident-Wisconsin}

\begin{tabular}{|c|c|c|}
\hline $\begin{array}{l}\text { Patient continued to ignore LEO } 1 \text { and Paramedic } 1 \text {. Patient } \\
\text { stretched again and said his feet hurt. }\end{array}$ & 18:00:10 & LEO 1 \\
\hline LEO 1 advised patient to sit on the cot; patient refused. & 18:01:04 & LEO 1 \\
\hline LEO 2 arrived on the scene. & $18: 01: 30$ & LEO 1 \\
\hline $\begin{array}{l}\text { LEO } 2 \text { is briefed by LEO } 1 \text { and advised of patient's refusal to } \\
\text { be patted down. }\end{array}$ & $18: 02: 10$ & LEO 2 \\
\hline LEO 2 observed Paramedic 1 and patient. & $18: 02: 13$ & LEO 1 \\
\hline LEO 1 continued to talk to patient. & $18: 02: 30$ & LEO 1 \\
\hline $\begin{array}{l}\text { LEO } 1 \text { called supervisory lieutenant and explained scenario. } \\
\text { Patient continued to state why he "cannot go" to the hospital. }\end{array}$ & $18: 02: 58$ & LEO 1 \\
\hline $\begin{array}{l}\text { Patient argued with responders about his medical status. } \\
\text { Patient stated he did not need medical assistance. }\end{array}$ & $18: 03: 15$ & LEO 2 \\
\hline Patient refused to sit on cot. & $18: 03: 33$ & LEO 2 \\
\hline Patient stated he preferred not to go to hospital. & $18: 03: 53$ & LEO 2 \\
\hline $\begin{array}{l}\text { Patient stated he did not want to get checked out. Patient } \\
\text { stated that he needed to get home to his wife. Arguing } \\
\text { continued. }\end{array}$ & $18: 04: 20$ & LEO 2 \\
\hline $\begin{array}{l}\text { Patient was told by responders and transit employee he could } \\
\text { not get back on the bus if he was not medically cleared. }\end{array}$ & 18:04:39 & LEO 2 \\
\hline $\begin{array}{l}\text { Patient stated he had to get home and pay rent and that his } \\
\text { wife was in the hospital. Patient stated that his feet were } \\
\text { starting to really hurt. TS employee explained he had to be } \\
\text { medically evaluated before he could get back on the bus to go } \\
\text { home. }\end{array}$ & $18: 05: 27$ & LEO 2 \\
\hline $\begin{array}{l}\text { LEO } 2 \text { advised patient to let Paramedics take him to hospital } \\
\text { for an evaluation. }\end{array}$ & $18: 05: 35$ & LEO 2 \\
\hline Patient stated his legs had been hurting for a while. & $18: 06: 53$ & LEO 2 \\
\hline
\end{tabular}




\section{Career Firefighter Killed, a Police Officer and a Civilian Wounded When They Were Shot During EMS Incident-Wisconsin}

\begin{tabular}{|c|c|c|}
\hline LEO 1 re-approached patient. & $18: 06: 59$ & LEO 2 \\
\hline $\begin{array}{l}\text { LEO } 1 \text { spoke with patient and explained voluntary treatment } \\
\text { versus medical detention involving a Crisis Center evaluation. }\end{array}$ & $18: 07: 02$ & LEO 1 \\
\hline Patient again said he “cannot” go to the hospital. & $18: 07: 14$ & LEO 2 \\
\hline LEO 1 explained to patient why he needed medical attention. & $18: 07: 20$ & LEO 2 \\
\hline Patient said he took morphine, not opioids. & $18: 07: 50$ & LEO 2 \\
\hline $\begin{array}{l}\text { Patient took deep breaths, crossed his arms, and said, “No, } \\
\text { man.” LEO } 1 \text { explained voluntary treatment versus medical } \\
\text { detention involving a Crisis Center Evaluation again. }\end{array}$ & 18:08:11 & LEO 1 \\
\hline LEO 2 moved behind to view patient’s body from behind. & 18:08:15 & LEO 2 \\
\hline $\begin{array}{l}\text { LEO } 1 \text { again explained voluntary treatment versus medical } \\
\text { detention involving a Crisis Center evaluation. }\end{array}$ & $18: 08: 24$ & LEO 2 \\
\hline $\begin{array}{l}\text { LEO } 2 \text { asked patient, “Real quick, do you have any } \\
\text { weapons?” }\end{array}$ & $18: 08: 41$ & LEO 2 \\
\hline Patient responded, “No Sir.” & $18: 08: 42$ & LEO 2 \\
\hline $\begin{array}{l}\text { LEO } 2 \text { asked about weapons again and identified a bulge on } \\
\text { patient's right side. }\end{array}$ & 18:08:43 & $\begin{array}{l}\text { LEO 1/ LEO } \\
2\end{array}$ \\
\hline Patient stated, “that’s my phone.” & $18: 08: 43$ & LEO 2 \\
\hline LEO 2 told patient, “don’t reach for it.” & $18: 08: 47$ & LEO 2 \\
\hline $\begin{array}{l}\text { LEO } 2 \text { attempted to pat down patient but was physically } \\
\text { grabbed by patient and deflected away. }\end{array}$ & $18: 08: 47$ & LEO 1 \\
\hline $\begin{array}{l}\text { Patient stated, "I have a problem with officers touching me } \\
\text { man. I get nervous and stuff." }\end{array}$ & 18:08:51 & LEO 2 \\
\hline LEO 1 stated twice "Lift up your shirt then.” & 18:08:54 & LEO 1 \\
\hline LEO 2 stated "Lift up your shirt then.” & 18:08:55 & LEO 1 \\
\hline
\end{tabular}




\section{Career Firefighter Killed, a Police Officer and a Civilian Wounded When They Were Shot During EMS Incident-Wisconsin}

\begin{tabular}{|c|c|c|}
\hline LEO 1 stated "we want to make sure everybody is safe." & 18:08:59 & LEO 1 \\
\hline $\begin{array}{l}\text { Patient reached under his shirt with his right hand, flipped } \\
\text { open the phone case. }\end{array}$ & 18:08:58 & LEO 2 \\
\hline $\begin{array}{l}\text { LEO 1, LEO 2, FF 1, FF 2, FF 3, TS Security Officer, } \\
\text { Paramedic 1, and Paramedic } 2 \text { can all be seen gathered in } \\
\text { front of bus. Patient cannot be seen by this camera. }\end{array}$ & 18:09:00 & TS CCTV \\
\hline LEO 2 yelled “Don’t reach! Don’t reach!” & 18:09:02 & LEO 2 \\
\hline $\begin{array}{l}\text { Shooting started. LEO } 2 \text { had service weapon drawn and faced } \\
\text { west. Everyone appeared alert and starting to move. FF 1, FF } \\
\text { 3, Paramedic 1, and TS Security Officer moved south. FF } 2 \\
\text { and Paramedic } 2 \text { moved north. }\end{array}$ & 18:09:04 & TS CCTV \\
\hline $\begin{array}{l}\text { LEO } 2 \text { continued to face west as Paramedic } 2 \text { moved north } \\
\text { and FF } 1 \text { moved south. FF } 1 \text { had his back exposed to the } \\
\text { shooting. }\end{array}$ & 18:09:05 & TS CCTV \\
\hline $\begin{array}{l}\text { LEO } 2 \text { continued to face west as FF } 1 \text { moved to the south with } \\
\text { his arms near his torso and began to stumble to the concrete. }\end{array}$ & 18:09:06 & TS CCTV \\
\hline TS Security Officer entered the TS. & 18:09:06 & TS CCTV \\
\hline $\begin{array}{l}\text { FF } 1 \text { stumbled to the concrete and rolled to the south. His left } \\
\text { hand was near his torso. }\end{array}$ & 18:09:07 & TS CCTV \\
\hline FF 1 tried to get up with both hands near his torso. & 18:09:09 & TS CCTV \\
\hline $\begin{array}{l}\text { FF } 1 \text { lay on his back. LEO } 1 \text { moved to the rear of bus on the } \\
\text { driver's side with handgun pointed towards the northwest. }\end{array}$ & 18:09:11 & TS CCTV \\
\hline LEO 1 notified “shots fired.” & 18:09:21 & LEO 1 \\
\hline $\begin{array}{l}\text { FF } 3 \text { went out the door of the TS and pointed toward FF } 2 \text { and } \\
\text { Paramedic } 2 \text {. FF } 3 \text { re-entered building, turned around, and } \\
\text { went back outside. FF } 3 \text { then saw FF } 1 \text { on the ground and } \\
\text { went toward him. }\end{array}$ & 18:09:23 & TS CCTV \\
\hline
\end{tabular}




\section{Career Firefighter Killed, a Police Officer and a Civilian Wounded When They Were Shot During EMS Incident-Wisconsin}

\begin{tabular}{|c|c|c|}
\hline $\begin{array}{l}\text { FF } 3 \text { saw FF } 1 \text { and went to him from the northwest entrance of } \\
\text { the TS and waved FF } 2 \text { and Paramedic } 2 \text { over to assist. }\end{array}$ & 18:09:44 & TS CCTV \\
\hline $\begin{array}{l}\text { FF } 2 \text { and Paramedic } 2 \text { left their cover and ran to FF } 3 \text { and FF } \\
1 .\end{array}$ & 18:09:56 & TS CCTV \\
\hline Cardiopulmonary resuscitation was started on FF 1. & $18: 10: 25$ & TS CCTV \\
\hline $\begin{array}{l}\text { FF } 1 \text { was loaded on cot. Cardiopulmonary resuscitation } \\
\text { continued. }\end{array}$ & $18: 11: 40$ & TS CCTV \\
\hline $\begin{array}{l}\text { FF 2, FF 3, and Paramedic } 2 \text { pushed the cot to north and } \\
\text { loaded FF } 1 \text { onto an ambulance }\end{array}$ & $18: 12: 34$ & TS CCTV \\
\hline Ambulance with FF 1 left the scene for the hospital. & 18:13:12 & TS CCTV \\
\hline
\end{tabular}

\section{Personal Protective Equipment}

At the time of the incident, the victim (FF 1), was wearing his station uniform, bunker pants and boots.

\section{Weather}

At approximately 5:30 p.m. Central Daylight Time, the weather in the immediate area was reported to be approximately 72 degrees Fahrenheit with a dew point of 37 degrees Fahrenheit and relative humidity of 29\%. Wind conditions were 6 miles per hour from the south and partly cloudy with visibility of 10 miles [Weather Underground 2019]. Weather was not considered to be a contributing factor in this incident.

\section{Investigation}

On May 15, 2019, a career firefighter was fatally shot by a patient who had overdosed (referred to as “patient” in this report and also "patient/shooter" after opening fire) while on an EMS call. A police officer and a civilian were also injured after being shot.

At approximately 5:30 p.m., Engine 9321 and a private ambulance company crew consisting of two paramedics were dispatched to a patient who reportedly had a seizure on a public intercity bus at a transit station. The Engine 9321 consisted of a crew of 3 firefighters. The victim was a member of this crew. He was a career firefighter and was working at his normal duty station. A police officer also responded to the scene to assist the fire and EMS units. He was first on the scene.

Upon arrival at the scene, the responders found the patient seated in the rear of the bus. The patient was unresponsive. The patient had agonal (abnormal and inadequate) breathing and pinpoint pupils. Based on this initial assessment, the responders determined that opioid overdose was more likely than 


\section{Career Firefighter Killed, a Police Officer and a Civilian Wounded When They Were Shot During EMS Incident-Wisconsin}

seizure. The firefighters inserted a nasopharyngeal airway and provided bag-valve-mask ventilation with oxygen. A paramedic from the private ambulance company inserted an intravenous line. Once intravenous access was established, a paramedic from the ambulance company administered $0.5 \mathrm{mg}$ of naloxone intravenously. The patient resumed spontaneous respiration and became responsive to stimuli. According to the private ambulance company's patient care report, due to "the lack of practical extrication methods," a second 0.5-mg dose of naloxone was given several minutes later "to allow the patient [to] self-extricate from the bus." The patient become fully responsive after the second dose of naloxone. The nasopharyngeal airway and ventilation were discontinued. The intravenous access was not removed.

The patient and responders exited the bus. A second police officer arrived as the responders and the patient were discussing transport to a hospital for further evaluation and treatment. The police officers asked the patient repeatedly if he had anything on his person that could harm the fire and/or EMS responders and requested to conduct a pat-down. Because the responders believed that the naloxone would wear off and that the patient would need further emergency medical assistance, they were attempting to talk the patient into being transported to the local hospital for follow-up medical care when the patient abruptly produced a handgun. The patient/shooter began firing shots at the EMS and fire crews and police officers. The EMS and fire crews and police officers ran for cover while the police officers returned fire. The patient/shooter and police officers exchanged gun fire while the patient/shooter took a civilian hostage and continued to fire until he was shot and secured in custody.

One firefighter (the workplace victim) was shot and collapsed while running for protection. A police officer was shot and injured while returning gun fire. The civilian hostage was also shot and injured. The firefighter was found unresponsive and immediately treated at the scene. The firefighter was transported to a local hospital by the ambulance that was on scene and was pronounced dead. The injured police officer was transported to the hospital by a fellow police officer and the civilian was transported by an additional ambulance to a hospital for care. The police officer and the civilian subsequently recovered from their injuries. The patient/shooter was provided treatment for his injuries and transported to a local hospital where he was pronounced dead.

\section{Contributing Factors}

Occupational injuries and fatalities are often the result of one or more contributing factors or key events in a larger sequence of events that ultimately result in the injury or fatality. NIOSH investigators identified the following items as key contributing factors in this incident that ultimately led to the fire fighter fatality:

- Medical Emergency: The incident began as a medical emergency in which the patient (prior to the shooting) was not breathing adequately and required emergency medical attention. An autopsy confirmed the patient/shooter had methamphetamine, fentanyl, and 4-anilino- $N$ phenethyl-piperidine (4-ANPP, a metabolite of fentanyl or fentanyl analogues) in his system.

- Scene Safety and Situational Awareness: After being revived with intravenous naloxone and exiting the bus under his own power, the patient produced a concealed handgun and fired at 


\section{Career Firefighter Killed, a Police Officer and a Civilian Wounded When They Were Shot During EMS Incident-Wisconsin}

numerous firefighters, police officers, EMS, transit workers, and civilians. Prior to the shooting, police officers made multiple attempts but did not complete a search of the patient.

\section{Cause of Death}

According to the medical examiner report, the firefighter died from a gunshot wound.

\section{Recommendations}

Recommendation \#1: First responders and agencies who deliver medical assistance to patients who overdose should train staff on SOPs for naloxone administration, including an understanding of the objective of naloxone therapy and the possibility, albeit uncommon, of agitation and combativeness from persons after receiving naloxone.

Naloxone is a medication that temporarily reverses the effects of opioids. It can be given through an intranasal spray, into a muscle (intramuscular), under the skin (subcutaneous), or injected into a vein (intravenous) or the bone marrow (intraosseous). It works by blocking mu-opioid receptors in the body so opioids cannot exert their effect. Naloxone does not reverse overdoses from other drugs such as alcohol, benzodiazepines, cocaine, or amphetamines. Naloxone has a serum half-life of 30-90 minutes [Lynn and Galinkin 2018], which means that it is possible for its effects to wear off before the effects of some longer-acting opioids wear off. Partly because of this, over $90 \%$ of patients in the United States who receive naloxone from EMS providers are transported to the emergency department for more definitive treatment [Faul et al. 2017].

The objective of naloxone therapy administration by trained first responders and other medical personnel is to maintain adequate oxygenation and ventilation without provoking opioid withdrawal [Lavonas et al. 2015; National Association of State EMS Officials (NASEMSO) 2019]. A technical expert panel convened by NASEMSO in collaboration with the National Association of EMS Physicians and the American College of Emergency Physicians does not recommend giving an initial dose of naloxone sufficient to achieve full consciousness. In addition, repeat naloxone dosing should be administered only if the initial dose was inadequate or respiratory depression recurs [Williams et al. 2019]. The fire department's standard operating guidelines recognized this objective by reminding department members that upon naloxone administration "[patients] may not wake up ... we are only trying to increase respiratory drive.” While the appropriate dose of naloxone is one that will restore and maintain respiratory function, the ideal dose of naloxone is not known [Lavonas et al. 2015].

Restoring full consciousness is not required for patient safety. Instead, it might precipitate withdrawal and agitation, reducing both patient safety and first responder safety. Symptoms of acute opioid withdrawal include irritability and agitation as well as body aches, increased heart rate, nausea and vomiting, diarrhea, increased tearing, runny nose, sweating, yawning, and goosebumps. Withdrawal symptoms are unpleasant but by themselves are not life-threatening to the patient [Clarke et al. 2005; Boyer 2012]. In addition, persons who receive naloxone might be upset that euphoric effects from opioids were halted [Feldman 2018]. 


\section{Career Firefighter Killed, a Police Officer and a Civilian Wounded When They Were Shot During EMS Incident-Wisconsin}

By reversing the effects of opioids, naloxone might also induce agitation and combativeness by unmasking the effects of other substances that patients who overdose might have also used. Regardless of cause, agitation and combativeness after naloxone administration can pose safety concerns to the patient and first responders [Williams et al. 2019]. In a previous NIOSH health hazard evaluation of firefighter-EMS providers, 2 of 32 firefighters (4\%) who had administered naloxone in the past 12 months as part of their job duties reported being injured on multiple occasions by a patient after naloxone administration. The incidents involved being kicked or being shoved downstairs or against a dresser [NIOSH 2017]. In a study of patients who received naloxone from EMS providers, 13\% experienced agitation or combativeness [Belz et al. 2006].

Relevant agency SOPs should be followed in all emergency settings. To the extent feasible, naloxone therapy should be guided by the goal of respiratory support, and this goal should be incorporated into applicable SOPs. Since serious side effects from naloxone are very rare and giving naloxone to an unconscious person not experiencing opioid toxicity is very unlikely to cause further harm, considerations about dosing should not stop laypersons or first responders from giving naloxone to reverse opioid overdoses, which are potentially life-threatening.

In this incident, interviews with responders and reviewing the ambulance run report indicated that the patient was initially unresponsive and had agonal breathing and pinpoint pupils. After an initial $0.5 \mathrm{mg}$ dose of intravenous naloxone, the patient resumed spontaneous respiration and became responsive to painful stimuli. A few minutes later, responders decided to give a second dose of naloxone "to allow [him to] self-extricate from the bus," which resulted in the patient becoming fully responsive and able to walk off the bus.

While it is not certain that stopping naloxone administration when the patient resumed breathing could have prevented the firefighter fatality, fire departments and other agencies that deliver medical care to patients who overdose should consider additional training on the objectives of naloxone therapy and the possibility for agitation and combativeness from persons after receiving naloxone. Fire departments and EMS agencies should also consider revising procedures to reinforce understanding of the objective of naloxone therapy and the administration of naloxone to meet the objective of respiratory support.

\section{Background on the opioid overdose epidemic}

The United States is currently in the midst of a drug overdose epidemic. First responders are likely to encounter drug overdoses in the course of their work, as shown by the statistics from multiple data sources outlined below.

First, the number of drug overdose deaths in the United States has been increasing [CDC 2020d,e]. In 2018, there were 67,367 drug overdose deaths, which corresponds to approximately 185 drug overdose deaths in the United States every day [Centers for Disease Control and Prevention (CDC) 2020a]. This represented a 50\% increase from the drug overdose death rate in 2013, when the current wave of the opioid overdose epidemic marked by increases in deaths involving synthetic opioids began [CDC 2020c]. Opioids, especially synthetic opioids such as fentanyl and its analogues, are currently the main driver of drug overdose deaths. Although data from 2018 showed slight declines in the number of drug 


\section{Career Firefighter Killed, a Police Officer and a Civilian Wounded When They Were Shot During EMS Incident-Wisconsin}

overdose deaths overall [CDC 2020b,c], provisional data suggest that the number of overdose deaths from all drug and synthetic opioids has increased in 2019 and 2020 [CDC 2020d]. Approximately 70\% of all drug overdose deaths in 2018 involved an opioid [CDC 2020b].

In Wisconsin, 1,075 people died from a drug overdose in 2018, representing a 28\% increase from 2013 [Wisconsin Department of Health Services 2020]. Opioids were involved in 78\% of drug overdose deaths in the state in 2018. Since 2013, the number of deaths involving synthetic opioids such as fentanyl in Wisconsin increased more than six times, from 80 deaths in 2013 to 504 deaths in 2018 [Wisconsin Department of Health Services 2020].

Second, the number of emergency department visits for suspected opioid overdoses has increased recently. During July 2016-September 2017, the number of emergency department visits for suspected opioid overdoses increased approximately 30\% in the United States and 109\% in Wisconsin [CDC 2018a].

Third, the number of EMS calls during which naloxone has been administered has increased [CDC 2018b; Faul et al. 2017]. Based on a national database of EMS events, there was an 82\% increase in the number of patients who received naloxone from 95,012 in 2012 to 173,016 in 2015 [Faul et al. 2017]. Most of the 911 calls that resulted in naloxone administration (83.3\%) did not specify drug ingestion or poisoning as the medical emergency [Faul et al. 2017].

Opioid overdose deaths have been described as occurring in three waves [CDC 2018c]. The first wave began with increased prescribing of opioids in the 1990s, which was associated with increases in overdose deaths due to prescription opioids. In the second wave, there were rapid increases in overdose deaths due to heroin, starting in 2010. The third wave, which began in 2013, corresponds to increases in overdose deaths involving synthetic opioids. In particular, fentanyl and fentanyl analogues have been implicated in this third wave, which is currently evolving.

\section{Recommendation \#2: Fire, EMS, and police departments and agencies who deliver medical assistance should develop SOPs that address the possibility of polydrug overdoses.}

Recent reports suggest that opioids are commonly used with other substances. A recent analysis found that deaths from illicitly manufactured fentanyl increased in 2017-2018 and that stimulants were also present in approximately 60\% of opioid-involved deaths [CDC 2019, 2020 a,b,c]. During JanuaryJune 2019, almost one-third of drug overdose deaths involved a combination of opioids and stimulants such as cocaine, methamphetamine, other illicit stimulants, and prescription stimulants [CDC 2020a]. Among non-fatal drug overdoses treated in emergency departments, the rate of overdoses that involved both opioids and amphetamines increased from 2018 to 2019 [CDC 2020d]. In addition, among urine drug tests done as part of routine medical care, the percentage of cocaine-positive and methamphetamine-positive samples that were also positive for fentanyl increased over time. By 2018, the percentage of co-positive samples ranged from $7.9 \%$ for methamphetamine and fentanyl to $17.6 \%$ for cocaine and fentanyl [LaRue et al. 2019]. Law enforcement data sources also suggest that fentanyl is being mixed with other drugs such as cocaine and methamphetamine [CDC 2018d]. Acute effects of stimulants such as cocaine and methamphetamine can be associated with agitation, restlessness, and anxiety [Aronson 2016; Cruickshank and Dyer 2009]. 


\section{Career Firefighter Killed, a Police Officer and a Civilian Wounded When They Were Shot During EMS Incident-Wisconsin}

In this incident, postmortem toxicology reports for the patient/shooter indicated the presence of methamphetamine, among other compounds. In general, amphetamines stimulate the central nervous system. Acute effects of methamphetamine include euphoria, elevated heart rate and blood pressure, increased alertness, behavioral disinhibition, and anxiety. At higher doses, methamphetamine can induce psychosis [Cruickshank and Dyer 2009].

The relationship between the patient/shooter's actions and the presence of methamphetamine detected on postmortem toxicology cannot be determined with certainty. The presence of methamphetamine during testing at a single point in time does not indicate that the patient/shooter used methamphetamine chronically. While some studies suggest an association between methamphetamine use and homicide [Ellinwood 1971; Stretesky 2009], these studies involved individuals with chronic methamphetamine use, which is associated with changes in the brain [Cruickshank and Dyer 2009]. While methamphetamine use might be associated with several mechanisms that may motivate violence, such as inhibition of cues that normally control behavior, increased arousal, interference with interpersonal communication, and intensification of emotions, violent behavior is not inevitable even with chronic methamphetamine use [Sommers and Baskin 2006]. The presence of methamphetamine during testing at a single point in time does not indicate that the patient/shooter was a chronic methamphetamine user.

Furthermore, it is not possible to estimate the time of last use or methamphetamine concentration in the blood or brain prior to death from a postmortem toxicology test. Reasons include uncertainties about the dose used, timing of last use, route of administration, and rate of drug movement from other parts of the body into the bloodstream after death, a phenomenon called postmortem redistribution [Logan 2001; Schepers et al. 2003].

Additionally, recognizing the potential for agitation and combativeness from persons who have received naloxone, fire, EMS, and police departments should develop ways to coordinate responses to ensure scene safety if necessary. Other recommendations in this report provide guidance on actions that fire, EMS, and police departments can take to ensure scene and personnel safety.

Recommendation \#3: Fire, EMS, and police departments should take steps to ensure scene safety including taking all necessary actions to protect themselves when providing lifesaving care to a patient. The fire service and standards setting organizations should consider developing scene safety SOPs and training that provide more detailed guidance on the specifics of keeping first responders safe while providing lifesaving care to patients.

Every situation is unique and has the potential to be unpredictable and should be treated as such by all responders, including the fire service. This event began with providing lifesaving care to a patient. The situation then very abruptly developed into an incident of workplace violence that resulted in the death of a firefighter by firearm homicide. Scene safety is critical to every response and should be an ongoing process throughout every response.

There are many references to scene safety in numerous trade journals for firefighters and EMS providers. Guidance about scene safety is generally outlined in NFPA 1500 [NFPA 2018a]. NFPA 3000 [NFPA 2018b] provides an outline of what an Active Shooter/Hostile Response (ASHER) 


\section{Career Firefighter Killed, a Police Officer and a Civilian Wounded When They Were Shot During EMS Incident-Wisconsin}

program should include. There are many different sources and variations of information and training that responders can receive regarding scene safety. A generic SOP template that could be adapted by each Authority Having Jurisdiction (AHJ) could be useful to the fire service as well as EMS providers to help standardize some of this information. The fire service and standard setting organizations should collaborate to develop best practices and training standards and/or SOPs that provide more detailed guidance on the specifics of scene safety assessment and the process of re-evaluating a scene as it changes throughout a response. Such an approach benefits both responders and members of the public.

At a minimum the SOPs should include all local resource capabilities, i.e., agencies and entities such as law enforcement, fire, EMS, and local hospitals. The SOPs should be based on a current risk assessment and should provide information on the scope and purpose of the SOP, how the health and safety of responders will be maintained, a guide for response actions, and mental health and recovery of the responders after an incident. The AHJ should ensure that plans are developed, maintained, evaluated by training and exercises, and updated as needed by all fire, EMS and police departments.

In this incident, while the patient was receiving medical assistance on the bus, it was clear that the scene was safe for law enforcement, firefighters, and paramedics to perform their duties. However, a scene should be re-evaluated periodically as the situation evolves. After the patient exited the bus under his own power, two law enforcement officers spoke with the patient about the need to determine if he had anything on him that could harm the paramedics or firefighters at the scene when they transported him to the hospital for further medical evaluation. This was part of the ongoing scene safety assessment.

In addition to the two law enforcement officers performing a scene safety assessment, there were two private ambulance company paramedics, three firefighters, two transit station employees, and one bus driver within several feet of the patient. Therefore, a total of 10 people were working within a few feet of the patient before this phase of the scene safety assessment was complete. Of those 10 workers, it appears that everyone except the bus driver was actively engaged in the conversation with the patient or monitoring the situation. (The bus driver did not engage the patient; he was preparing to back the bus away from the scene when shots were fired.)

In this incident it was clear from the multiple requests by law enforcement to search the patient that the responders did not know if the patient had anything on his person that could harm the patient or the responders. During the interviews, some of the fire and EMS responders indicated they stayed near the patient in order to either provide further medical assistance to the patient and/or to assist law enforcement. Fire department company officers and unit leaders should help to ensure that while some of the responders may need to be in close proximity of the patient, they may not all need to be. All of the responders should be aware of and act in their specific roles as needed by each event.

Given that any situation can change rapidly, unit or company officers should continually alert their crews to threats and position crews accordingly. There should be an ongoing assessment of an incident until the incident is determined to be under control. It is prudent to limit the number of firefighters, EMS providers, and other workers who are not actively engaged in scene safety assessment or patient care to be in close proximity until law enforcement has been able to determine if the scene is secure and safe. 


\section{Career Firefighter Killed, a Police Officer and a Civilian Wounded When They Were Shot During EMS Incident-Wisconsin}

\section{Scene Safety Background}

Additional information from the annex of NFPA 1500 Standard on Fire Department Occupational Safety, Health, and Wellness Program states that:

- Fire department members should not enter an environment where there is ongoing violence, or the threat of violence such as a person with weapons, without coordination with law enforcement personnel. This does not necessarily limit the ability of cross-trained fire/law enforcement personnel or specialty trained EMS providers from entering a violent scene to assist the law enforcement or fire department responders.

- Such situations include but are not limited to civil unrest, fights, violent crimes, drug-related situations, family disturbances, persons with altered mental status, and people interfering with fire department operations.

- The Firefighting Resources of California Organized for Potential Emergencies (FIRESCOPE) has developed ICS-701, Emergency Response to Tactical Law Enforcement Incidents [Firescope 2015], which might be useful in developing a standard operating procedure as per NFPA 1582 [NFPA 2018a].

Incidents that appear routine in nature can turn into a violent or hostile environment after the arrival of responding crews. A standard communication phrase, known only by communications personnel and other responders, can warn others of the dangers of the situation without triggering violence or hostilities. The "Mayday" or emergency button on a portable radio can also be used for responders to gain attention in a rapidly changing or escalating event. In many of the newer portable radios, once depressed, the emergency button provides an open airway (without the need for the responder to push a transmit button) for a number of seconds followed by a priority transmitting availability. This emergency button activates a signal at the emergency communications center requiring an action by a dispatcher.

The Essentials of Fire Fighting and Fire Department Operations defines situational awareness as "an awareness of the immediate surroundings” [IFSTA 2013]. All emergency responders operating at an incident need to maintain situational awareness and conduct a continuous risk assessment throughout the incident, reporting unsafe or changing conditions to the incident commander. Firefighters and emergency responders need to understand the importance of situational awareness and personal safety on the fireground.

On any emergency scene, every responder should be trained in situational awareness to be constantly alert for changing and unsafe conditions and be trained to avoid complacency. Situational awareness is a cognitive learned skill and it can be taught [NIOSH 2018]. This applies not only to conditions found directly related to the emergency scene (i.e., crash scene), but other hazards and dangers to the responder(s) from outside events or unsafe conditions or hostile environments. In order to have situational awareness, you must be able to perceive the threat, comprehend the threat, and predict what effect that threat may have on you. These elements-Perceive, Comprehend, and Predict-form the cornerstone of maintaining complete situational awareness [Brennan 2009, Gasaway 2013]. 


\title{
Career Firefighter Killed, a Police Officer and a Civilian Wounded When They Were Shot During EMS Incident-Wisconsin
}

\author{
Recommendation \#4: Authorities Having Jurisdiction (AHJs) (e.g. municipalities, areas, or \\ departments) should consider developing SOPs or guides that specify when (1) a patient should \\ receive a pat down to identify information that might be useful for patient care or identify items that \\ pose a threat to the patient or responders and (2) a patient might be restrained if the patient poses a \\ threat to themselves or the responders. These SOPs should specify who determines when a pat down \\ is necessary and who is authorized to perform it. These SOPs should be operationalized, trained, \\ and exercised by law enforcement, the fire service, and EMS as part of a Unified Command \\ response.
}

Conducting pat downs when warranted is an important part of patient care and scene safety assessments. Pat downs may reveal information that can more quickly identify potential causes of the medical issue (e.g., finding a bottle of nitroglycerine tablets in the patient's pocket) or provide other information that is important for patient care (e.g., medical alert bracelet or emergency contact information). Pat downs may also reveal an item that can be immediately harmful, such as a weapon (e.g., knife or firearm) as well as items that can inadvertently be harmful to responders (e.g., a sharp object such as a needle). A risk assessment should be performed to determine if a pat down is appropriate according to the AHJ's laws and SOPs. Identifying a potential harm to the patient or responder can save the life of the patient, first responder, or both.

In this incident, the police were attempting to perform a search of the patient when the patient produced a concealed handgun and fired at the first responders. If permissible under the AHJ's laws and SOPs, one possible option could have been to perform a pat down of the patient after life-saving therapy was performed on the bus (e.g., airway management and administration of the first dose of naloxone), but before he was able to walk off the bus on his own power without his weapon being secured by law enforcement.

While some practitioners recommend the use of physical restraints before naloxone administration to protect patients and EMS providers [Gaddis and Watson 1992], most patients do not become agitated or combative after naloxone therapy. Fire and EMS departments should carefully weigh considerations such as patient distress associated with being restrained upon reversal with naloxone, respect for patient dignity and patient rights, and other concerns against the likelihood of agitation and combativeness that would result in patient or EMS provider injury in their restraint protocols to guide restraint use on a case-by-case basis.

\section{Recommendation \#5: Public or mass transportation companies should consider equipping their terminals/stations with transfer/evacuation devices that are capable of fitting down the aisles for patient removal.}

A public or mass transportation company's emergency evacuation plan should include provisions for assisting personnel in moving people who have mobility issues. Numerous states have adopted legislation that requires building owners or operators to provide a means of egress for people with mobility impairments with minimum risk to the staff and the individual with impairments. Often this is accomplished by utilizing a transfer chair (see Photo 2). The general dimensions of transfer chairs vary but they are designed to fit narrow aisles on aircraft when assisting mobility impaired individuals on a 


\section{Career Firefighter Killed, a Police Officer and a Civilian Wounded When They Were Shot During EMS Incident-Wisconsin}

daily basis. Evacuation sleds or blankets could be another consideration for safely removing a mobility impaired patient depending on circumstances.

In this incident, the patient was unconscious and sitting in a window seat on the bus. The patient was above average in size and weight and there were concerns about being able to move him safely off the bus. The patient was brought out of his unconscious state primarily so that he could ambulate off the bus. If a narrow space transfer chair had been available, either on the bus or at the transit station, it may have been able to be used in the narrow aisle. The wheelchair hydraulic lift on the bus may have been able to be used to get the patient off the bus, thus avoiding administration of the second dose of naloxone.

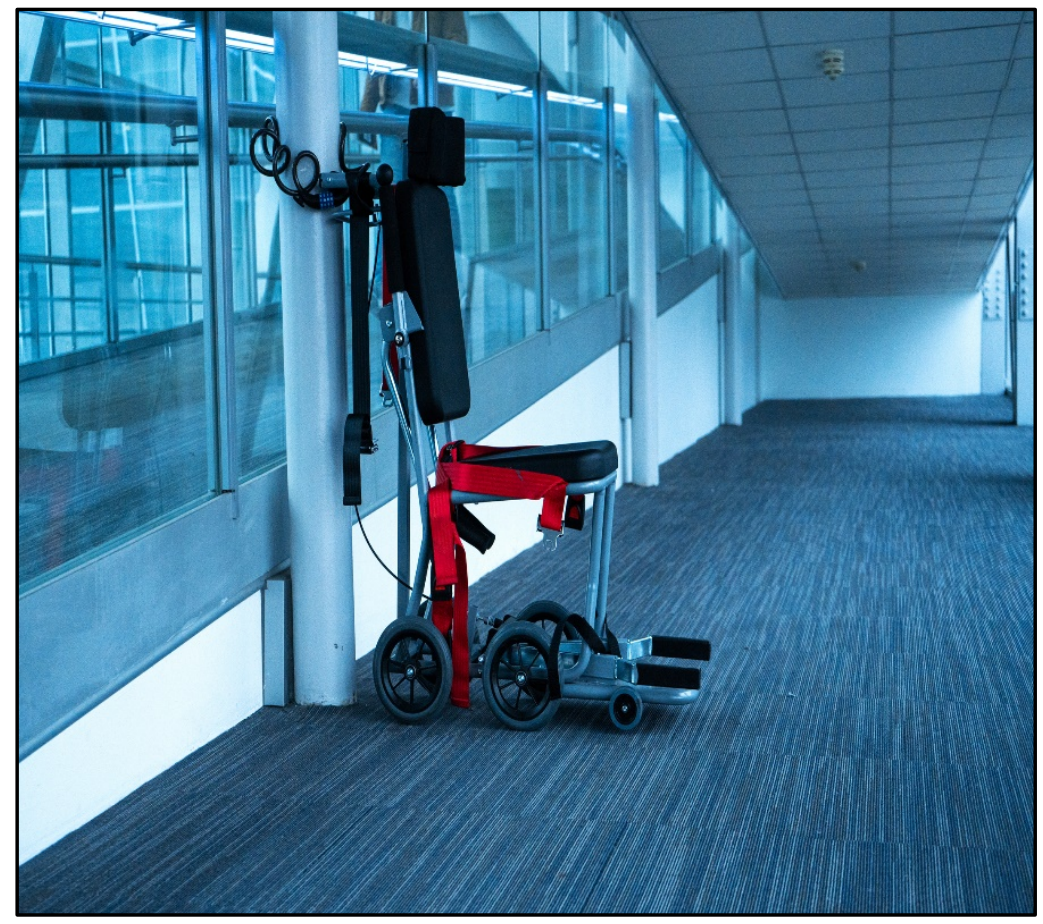

Photo 2. An example of a transfer chair ready for use in a transportation terminal. (Photo by (C) Kukota, Kateryna 2020/Getty Images).

Note: Although there is no evidence that the following recommendation would have prevented this fatality, it is being provided as a reminder of best practices for the fire service and other public safety agencies.

Recommendation \#6: Fire, EMS, police departments and dispatch agencies should ensure that all responders have the information needed for their response and safety. 


\section{Career Firefighter Killed, a Police Officer and a Civilian Wounded When They Were Shot During EMS Incident-Wisconsin}

All agencies receiving calls for assistance should ensure important information for the response and responder safety is asked during the call taking process and that information is transferred into the dispatch and communicated to individual responding units. Critical information, such as the suspected presence of weapons, that can assist first responders with their safety needs, should be obtained and transmitted to all of the responding units to an emergency if known. This information can help establish the proper response urgency and prepare responders to more fully consider their own safety [NIOSH 2005, 2016]. It may also be a communication benefit to relay this information by radio as well as putting notes in the warning or information section of the Mobile Data Terminal (MDT).

Firefighters and EMS providers may not be sitting in front of an MDT or be able to scroll through and read important case notes such as this during an emergency response. These important messages should have a priority screen presence with some sort of visual stimuli to ensure it is noticed. This is not only important for the primary units assigned, but also fire department and EMS supervisors for those units.

When sensitive information cannot or should not be transmitted over the radio, the dispatcher should verbally prompt responding units to check and acknowledge case notes to complete the communications loop.

In this incident, the communications center received a call for assistance for a patient who reportedly had a seizure. There were no signs of a hazardous or dangerous scene, nor were there any indications of the patient being armed with a handgun. Given the information available at the time, the responding fire engine, ambulance crew, and police officers had no reason to expect that the patient was armed with a handgun based upon the information provided in the call. 


\section{Career Firefighter Killed, a Police Officer and a Civilian Wounded When They Were Shot During EMS Incident-Wisconsin}

\section{References}

Aronson JK, ed. [2016]. Cocaine. Meyler's side effects of drugs. 16th ed. Waltham, MA: Elsevier.

Belz D, Lieb J, Rea T, Eisenberg MS [2006]. Naloxone use in a tiered-response emergency medical services system. Prehosp Emerg Care 10(4):468-471, http://dx.doi.org/10.1080/10903120600885134. Date accessed: October 2020.

Boyer EW [2012]. Management of opioid analgesic overdose. N Engl J Med 367(2):146-155, http://dx.doi.org/10.1056/NEJMra1202561. Date accessed: October 2020.

Brennan C [2009]. Situational awareness. Fire service warrior, November 3, 2009.

CDC [2018a]. Vital Signs: Trends in emergency department visits for suspected opioid overdoses United States, July 2016-September 2017. MMWR 67(9): 279-285,

https://dx.doi.org/10.15585/mmwr.mm6709e1. Date accessed: October 2020.

CDC [2018b]. Naloxone administration frequency during emergency medical service events — United States, 2012-2016. MMWR 67(31):850-853, http://dx.doi.org/10.15585/mmwr.mm6731a2. Date accessed: October 2020.

CDC [2018c]. Understanding the epidemic. Atlanta, GA: U.S. Department of Health and Human Services, Centers for Disease Control and Prevention, National Center for Injury Prevention and Control, https://www.cdc.gov/drugoverdose/epidemic/. Date accessed: October 2020.

CDC [2018d]. Rising numbers of deaths involving fentanyl and fentanyl analogs, including carfentanil, and increased usage and mixing with non-opioids. Health Alert Network Update 413. Atlanta, GA:

U.S. Department of Health and Human Services, Centers for Disease Control and Prevention, Office of Public Health Preparedness and Response, https://emergency.cdc.gov/han/han00413.asp. Date accessed: October 2020.

CDC [2019]. Changes in opioid-involved overdose deaths by opioid type and presence of benzodiazepines, cocaine, and methamphetamine - 25 States, July-December 2017 to January-June 2018. MMWR 68(34):737-744; http://dx.doi.org/10.15585/mmwr.mm6834a2. Date accessed: October 2020.

CDC [2020a]. Characteristics of drug overdose deaths involving opioids and stimulants — 24 States and the District of Columbia, January-June 2019. MMWR 69(35):1198-1197, http://dx.doi.org/10.15585/mmwr.mm6935a1. Date accessed: October 2020.

CDC [2020b]. Drug and opioid-involved overdose deaths — United States, 2017-2018. MMWR 69(11):290-297, http://dx.doi.org/10.15585/mmwr.mm6911a4. Date accessed: October 2020. 


\section{Career Firefighter Killed, a Police Officer and a Civilian Wounded When They Were Shot During EMS Incident-Wisconsin}

CDC [2020c]. Drug overdose deaths in the United States, 1999-2018. NCHS Data Brief, no 356. Hyattsville, MD: National Center for Health Statistics, https://www.cdc.gov/nchs/data/databriefs/db356-h.pdf. Date Accessed: October 2020.

CDC [2020d]. Increase in fatal drug overdoses across the United States driven by synthetic opioids before and during the COVID-19 pandemic. Health Alert Network Update 438. Atlanta, GA: U.S. Department of Health and Human Services, Centers for Disease Control and Prevention, Office of Public Health Preparedness and Response, https:/emergency.cdc.gov/han/2020/han00438.asp. Date accessed: December 2020.

CDC [2020e]. Nonfatal drug and polydrug overdoses treated in emergency departments — 29 States, 2018-2019. MMWR 69(34):1149-1155, http://dx.doi.org/10.15585/mmwr.mm6934a1. Date accessed: October 2020.

Clarke SF, Dargan PI, Jones AL [2005]. Naloxone in opioid poisoning: Walking the tightrope. Emerg Med J 22(9):612-616, http://dx.doi.org/10.1136/emj.2003.009613. Date accessed: October 2020.

Cruickshank CC, Dyer KR [2009]. A review of the clinical pharmacology of methamphetamine. Addiction 104(7):1085-1099, http://dx.doi.org/10.1111/j.1360-0443.2009.02564.x. Date accessed: October 2020.

C-TECC [2019]. Guidelines for First Responders with a Duty to Act. Committee for Tactical Causality Care. http://nspa1.org/wp-content/uploads/2020/09/4-2019_TECC_ALS_BLS_Guidelines_.pdf. Date Accessed: October 2020.

Ellinwood EH. [1971]. Assault and homicide associated with amphetamine abuse. Am J Psychiatry 127(9):1170-1175, http://dx.doi.org/10.1176/ajp.127.9.1170. Date accessed: Oct. 2020.

Feldman N [2018]. Opioid antidote can save lives but deciding when to use it can be challenging. Washington, DC: NPR, https:/www.npr.org/sections/health-shots/2018/10/29/660640838/opioidantidote-can-save-lives-but-deciding-when-to-use-it-can-be-challenging. Date accessed: Oct. 2020.

Faul M, Lurie P, Kinsman JM, Dailey MW, Crabaugh C, Sasser SM [2017]. Multiple naloxone administrations among emergency medical service providers is increasing. Prehosp Emerg Care 21(4):411-419, http://dx.doi.org/10.1080/10903127.2017.1315203. Date accessed: Oct. 2020.

Firescope [2015]. Firefighting Resources of California Organized for Potential Emergencies (FIRESCOPE). ICS-701, Emergency Response to Tactical Law Enforcement Incidents https://firescope.caloes.ca.gov/ICS\%20Documents/ICS\%20701.pdf. Date accessed: Oct. 2020.

Gaddis GM, Watson WA. Naloxone-associated patient violence: an overlooked toxicity? Ann Pharmacother, 26(2), 196-198, https://dx.doi.org/10.1177/106002809202600211. Date accessed: Oct. 2020. 


\section{Career Firefighter Killed, a Police Officer and a Civilian Wounded When They Were Shot During EMS Incident-Wisconsin}

Gasaway RB [2013]. Situational awareness for emergency response. Tulsa, OK: PennWell.

IAFF [2017]. Mitigation of occupational violence to firefighters and EMS responders. Washington, DC: International Association of Firefighters, Federal Emergency Management Agency contract no. HSFE20-15-Q-0053, https://www.usfa.fema.gov/downloads/pdf/publications/mitigation_of_occupational_violence.pdf. Date accessed: Oct. 2020.

IFSTA [2013]. Essentials of fire fighting. Stillwater, OK: Fire Protection Publications, International Fire Service Training Association.

LaRue L, Twillman RK, Dawson E, Whitley P, Frasco MA, Huskey A, Guevara MG [2019]. Rate of fentanyl positivity among urine drug test results positive for cocaine or methamphetamine. JAMA Network Open 2(4):e192851-e192851, http://dx.doi.org/10.1001/jamanetworkopen.2019.2851. Date accessed: Oct. 2020.

Lavonas EJ, Drennan IR, Gabrielli A, Heffner AC, Hoyte CO, Orkin AM, Sawyer KN, Donnino MW [2015]. Part 10: Special circumstances of resuscitation. Circulation 132(18):S501-S518, http://dx.doi.org/doi:10.1161/CIR.0000000000000264. Date accessed: Oct. 2020.

Logan BK [2001]. Amphetamines: An update on forensic issues. J Anal Toxicol 25(5):400-404, http://dx.doi.org/10.1093/jat/25.5.400. Date accessed: Oct. 2020.

Lynn R, Galinkin JL [2018]. Naloxone dosage for opioid reversal: Current evidence and clinical implications. Ther Adv Drug Saf 9(1):63-88, http://dx.doi.org/10.1177/2042098617744161. Date accessed: Oct. 2020.

NASEMSO [2019]. Model EMS protocol relating to naloxone administration by EMS personnel. Falls Church, VA: National Association of State EMS Officials, https://nasemso.org/wpcontent/uploads/Model-EMS-Protocol-Relating-to-Naloxone-Administration-by-EMS-Personnel.pdf. Date accessed: Oct. 2020.

NFPA [2013a]. NFPA 1001 Standard for Firefighter Professional Qualifications, 2013 edition. National Fire Protection Association, Quincy MA.

NFPA [2013b]. NFPA 1582 Standard on Comprehensive Occupational Medical program for fire departments, 2018 edition. National Fire Protection Association, Quincy MA.

NFPA [2018a]. NFPA 1500 Standard on Fire Department Occupational Safety and Health Program, 2018 edition. National Fire Protection Association, Quincy MA.

NFPA [2018b]. NFPA 3000: Standard for an Active Shooter/Hostile Event Response (ASHER) Program, 2018 edition. National Fire Protection Association, Quincy MA. 


\section{Career Firefighter Killed, a Police Officer and a Civilian Wounded When They Were Shot During EMS Incident-Wisconsin}

NIOSH [1996]. Violence in the workplace. Cincinnati, OH: U.S. Department of Health and Human Services, Centers for Disease Control and Prevention, National Institute for Occupational Safety and Health, DHHS (NIOSH) Publication No. 96-100, https://www.cdc.gov/niosh/docs/96-100. Date accessed: October 2020.

NIOSH [2005]. Career lieutenant killed and fire fighter injured by gunfire while responding to medical assistance call - Kentucky. Morgantown, WV: U.S. Department of Health and Human Services, Centers for Disease Control and Prevention, National Institute for Occupational Safety and Health, F2004-11. https:/www.cdc.gov/niosh/fire/reports/face200411.html. Date accessed: October 2020.

NIOSH [2014]. Shift safety officer falls through hole in floor into basement of a vacant row house and dies from smoke inhalation - Maryland. By Merinar T., Loflin M. Morgantown, WV: U.S. Department of Health and Human Services, Centers for Disease Control and Prevention, National Institute for Occupational Safety and Health, F2014-24. https://www.cdc.gov/niosh/fire/pdfs/face201424.pdf. Date accessed: October 2020.

NIOSH [2016]. Career fire fighter killed and volunteer fire fighter seriously wounded when shot during a civilian welfare check - Maryland. By Miles S.T., Merinar T. Morgantown, WV: U.S. Department of Health and Human Services, Centers for Disease Control and Prevention, National Institute for Occupational Safety and Health, F2016-06.

https://www.cdc.gov/niosh/fire/pdfs/face201606.pdf. Date accessed: October 2020.

NIOSH [2017]. Evaluation of fire fighters' mental health symptoms and exposure to traumatic events, job stress, and bloodborne pathogens. By Wiegand DM, Chiu S. Cincinnati, OH: U.S. Department of Health and Human Services, Centers for Disease Control and Prevention, National Institute for Occupational Safety and Health, Health Hazard Evaluation Report 2017-0021-3293, https://www.cdc.gov/niosh/hhe/reports/pdfs/2017-0021-3293.pdf. Date accessed: October 2020.

NIOSH [2018]. Career Captain Fatally Shot and a Fire Fighter Wounded by Arsonist while Responding to a Fire Alarm - California. By Bowyer M., Hales T. Morgantown, WV: U.S. Department of Health and Human Services, Centers for Disease Control and Prevention, National Institute for Occupational Safety and Health, F2018-11. https://www.cdc.gov/niosh/fire/pdfs/face201811.pdf. Date accessed: October 2020.

Peek-Asa C, Howard J, Vargas L, Kraus JF [1997]. Incidence of non-fatal workplace assault injuries determined from employer's reports in California. J Occup Environ Med 39(1):44-50, http://dx.doi.org/10.1097/00043764-199701000-00009. Date accessed: October 2020.

Schepers RJF, Oyler JM, Joseph RE, Cone EJ, Moolchan ET, Huestis MA [2003]. Methamphetamine and amphetamine pharmacokinetics in oral fluid and plasma after controlled oral methamphetamine administration to human volunteers. Clin Chem 49(1):121-132, http://dx.doi.org/10.1373/49.1.121. Date accessed: October 2020. 


\section{Career Firefighter Killed, a Police Officer and a Civilian Wounded When They Were Shot During EMS Incident-Wisconsin}

Sommers I, Baskin D [2006]. Methamphetamine use and violence. J Drug Issues 36(1):77-96, http://dx.doi.org/10.1177/002204260603600104. Date accessed: October 2020.

Stretesky PB [2009]. National case-control study of homicide offending and methamphetamine use. J Interpersonal Violence 24(6):911-924, http://dx.doi.org/10.1177/0886260508325011. Date accessed: October 2020.

USFA [2017]. Mitigation of Occupational Violence to Firefighters and EMS Responders. U.S. Fire Administration, 16825 South Seton Ave., Emmitsburg, MD 21727

https://www.usfa.fema.gov/downloads/pdf/publications/mitigation_of_occupational_violence.pdf. Date accessed: October 2020.

Weather Underground [2019]. Weather history for Appleton, WI, May 15, 2019, https://www.wunderground.com/history/daily/KATW/date/2019-5-

15?req_city=Appleton\&req_state=WI\&req_statename=Wisconsin\&reqdb.zip=54911\&reqdb.magic=1 \&reqdb.wmo=99999.

Williams K, Lang ES, Panchal AR, Gasper JJ, Taillac P, Gouda J, Lyng JW, Goodloe JM, Hedges M [2019]. Evidence-based guidelines for EMS administration of naloxone. Prehosp Emerg Care 23(6):749-763, http://dx.doi.org/10.1080/10903127.2019.1597955. Date accessed: October 2020.

Wisconsin Department of Health Services [2019]. Wisconsin EMS scope of practice. Madison, WI: Wisconsin Department of Health Services, Wisconsin Emergency Medical Services Section, https://www.dhs.wisconsin.gov/publications/p0/p00451.pdf. Date accessed: October 2020.

Wisconsin Department of Health Services [2020]. Wisconsin Interactive Statistics on Health (WISH) data query system, drug overdose deaths module. Madison, WI: Wisconsin Department of Health Services, Division of Public Health, Office of Health Informatics, https://www.dhs.wisconsin.gov/wish/index.htm. Date accessed: October 2020.

\section{Investigator Information}

This incident was investigated by Stephen T. Miles, Investigator/Safety and Occupational Health Specialist, and Matt Bowyer, Investigator/General Engineer with the Firefighter Fatality Investigation and Prevention Program, Surveillance and Field Investigations Branch, Division of Safety Research, NIOSH located in Morgantown, West Virginia. Additional NIOSH investigators and report co-authors were Dr. Sophia Chiu, Medical Officer, Hazard Evaluations and Technical Assistance Branch, Division of Field Studies and Engineering in Cincinnati, Ohio, and CAPT Jennifer Hornsby-Myers, industrial hygienist, U.S. Public Health Service, NIOSH Emergency Preparedness and Response Office in Morgantown, West Virginia. 


\section{Career Firefighter Killed, a Police Officer and a Civilian Wounded When They Were Shot During EMS Incident-Wisconsin}

An expert technical review was provided by Matthew Tobia, Fire Chief with the City of Harrisonburg, Virginia Fire Department. Chief Tobia is a thirty-year student of the fire service and past Chair of the of the International Association of Fire Chiefs Safety, Health and Survival Section.

A technical review was also provided by the National Fire Protection Association, Public Fire Protection Division.

\section{Disclaimer}

Mention of any company or product does not constitute endorsement by the National Institute for Occupational Safety and Health (NIOSH), Centers for Disease Control and Prevention. In addition, citations to websites external to NIOSH do not constitute NIOSH endorsement of the sponsoring organizations or their programs or products. Furthermore, NIOSH is not responsible for the content of these websites. All web addresses referenced in this document were accessible as of the publication date.

\section{Appendix A. Detailed description of the Public Safety Training Center.}

The Public Safety Training Center sits on 80 acres of land leased from the airport. This training center serves law enforcement, fire protection, and EMS professionals. The \$34.5 million project was made possible through a partnership with the AHJ airport and was funded through a district-wide referendum. It includes the following major elements:

- A 96,000 square-foot tactical lab and classroom building, which includes two indoor firing ranges, defensive tactics rooms, a fully equipped forensic laboratory, jail training area, EMS classrooms with an ambulance simulator, computer/dispatch laboratory, and an apparatus bay containing five double bays including a high bay for aerial trucks.

- A full emergency vehicle operation (EVOC) range with skid pad, skills pad, and pursuit track.

- Simulated village containing streets, intersections, two full-size residential homes and three commercial venues: gas station/convenience store, drive-up bank, and hotel/motel/bar. An additional building is designed for training forced entry, search and rescue, and tactical clearing.

- Comprehensive fire training ground, including a 6-story live burn tower, ladder training structure, numerous gas- or propane-fired props (e.g. car fire, residential and commercial gas meter fire, etc.), and technical rescue training facilities, including trench rescue, confined space and high- and low-angle rescue.

- A decommissioned Boeing 727 to be used for training on-board emergencies, such as medical emergencies, disruptive passengers, hostage situations, and so forth. A 3-car tank car simulated derailment to train response to hazardous material release. 


\section{Career Firefighter Killed, a Police Officer and a Civilian Wounded When They Were Shot During EMS Incident-Wisconsin}

- Four fully baffled outdoor firing ranges, including 50-yard, 100-yard, and a 300-yard sniper range with elevated platform.

- Currently under construction is a \$14 million addition in the form of an Aircraft Rescue and Fire Fighting (ARFF) live-burn training facility. When complete, it will contain an administrative building with two classrooms, three-bay apparatus room and a propane fueled aircraft frame (B-777) with multiple burn scenarios.

The fire department has a fire training site located at station 6 (also designated as the Special Operations Station). It houses most of the city's hazardous materials response capability along with their tactical hands-on training grounds. It contains county-wide assets that include an all-terrain vehicle and foam trailer. The Resource Development and Special Operations Division is located at Station 6 and under the direct supervision of a Battalion Chief. The division also includes a Training and Resource Development Specialist to assist in the day-to-day operations of the division.

The tactical training grounds consist of a 4-story concrete training tower. The building was developed to provide different building elevation on each side of the structure; including residential and commercial appearances. The facility is not designed for live fire but is able to provide simulated smoke conditions and utilize a Digital Fire Attack System which allows firefighters to locate and extinguish a simulated fire. There are additional venues that allow for ground and aerial ladders, ventilation, forcible entry, confined space rescue, rope rescue, building shoring, lifting and moving and concrete breeching.

In 2018, the department's division of training oversaw the annual basic skills assessment training that every member in the operations division completed. The division also oversaw the monthly safety committee facilitation and monthly training for firefighter, driver/engineer and company officer training. In 2018, the department recorded 12,558 hours of training. Annually, the department internally delivers a 6-week recruit fire academy for probationary firefighters. This academy is held at the training facility at Fire Station 6 and utilizes the Technical College's Public Safety Training Center for live burn and other specialty venues. Instructors in the academy include fire operations personnel assigned to fire stations throughout the city. Academy curriculum includes an orientation, lessons in fire behavior, the use of extinguishers, study of tools and equipment, discussions on communications and department policy, instruction on the use of ropes and knots, extensive training on personal protective equipment (PPE) and self-contained breathing apparatus (SCBA).

The academy utilizes classroom and practical training in ladders, fire hose, water supply, fire streams, forcible entry techniques, ventilation, search and rescue, salvage and overhaul, self-survival, and fire tactics. Members of the Fire Prevention and Public Education Division teach classes on fire detection and alarm systems, pre-plans, the basics of fire prevention, and about the many fire prevention and safety programs the department offers. The Special Operations Division teaches courses and practical evolutions in the areas of rope rescue and mechanical advantages, confined space rescue, hazardous materials response, and special equipment and techniques used in special operations.

In 2018, 31 department members trained at a higher level of water rescue and served as swift water rescue team members and rescue boat operators. Twenty-eight department members are designated as 
Career Firefighter Killed, a Police Officer and a Civilian Wounded When They Were Shot During EMS Incident-Wisconsin

swift water technicians. All members of the operations division receive annual in-the-water refresher training for water and ice rescue. 